\title{
TEATRO E IDENTIDADE NEGRA: AS NUANCES DA REPRESENTAÇÃO IDENTITÁRIA EM DESFUGA, DE UBIRAJARA FIDALGO
}

\author{
THEATER AND BLACK IDENTITY: THE NUANCES OF SELF INDENTITY \\ REPRESENTATION IN DESFUGA, BY UBIRAJARA FIDALGO
}

Recebido: 15/04/2021

Aprovado: 30/06/2021

DOI: $10.18817 /$ rlj.v5i01.2580

Publicado: $30 / 07 / 2021$

Elizeu Arruda de Sousa 1
Orcid ID: https://orcid.org/0000-0002-6729-6681
Ykaro Levy Marques Rosário²
Orcid ID: https://orcid.org/0000-0001-7668-3600

Resumo: O artigo, aqui em tela, firma-se no objetivo de examinar as diferentes formas como a representação da identidade negra é encarada pela personagem protagonista do monólogo teatral Desfuga, do dramaturgo caxiense/ maranhense Ubirajara Fidalgo. A peça escrita e encenada, inicialmente, na década de 1980, traz um percurso conflituoso de rejeição e aceitação da identidade afrodescendente pelo protagonista do texto dramático. Tal trajetória acaba por se identificar com tantas outras trilhadas por negros do Brasil dos anos 80- século XX- e até mesmo os da atualidade. Ubirajara Fidalgo utiliza o teatro, em tom de denúncia, como um instrumento de resistência ao racismo estrutural que ainda hoje é muito verificado. Informando sobre o procedimentos metodológicos que alicerçaram o presente estudo, realizou-se uma pesquisa bibliográfica voltada para teóricos que focalizam, em suas pesquisas, conceitos acerca da representação e identidade negra, tais como: Augel (2010), Bispo (2011), Hall (1997,2003, 2005), Santos (2015), Sousa (2018). Uma outra vertente de abordagem diz respeito às informações sobre a biografia e produção teatral de Ubirajara Fidalgo, fundamentadas por autores como: Fidalgo (2017), Freitas (2013), Rezende (2017), Santos (2014). Também é procedida a leitura e análise da peça teatral Desfuga, destacando-se e examinando-se os trechos em que são verificáveis as alternantes formas como o protagonista se relaciona com a identidade negra.

Palavras-Chave: Identidade negra. Resistência. Teatro.

Abstract: The objective of this article is to examine the different ways in which the representation of black identity is faced by the main character in the theatrical monologue Desfuga, by the playwright who was in Caxias, Ubirajara Fidalgo. The play, initially written and staged in the 1980s, brings a conflicting path of rejection and acceptance of the Afro-Brazilian identity by the protagonist of the dramatic text. Such path ends up being relatable with so many others black people in Brazil in the 1980 s - 20th century, even in our days. Ubirajara Fidalgo uses theater, in a tone of denounce, as an instrument of resistance to the structural racism that is still current in our day. Informing on the methodological procedures that grounded the present study, a bibliographical research was carried out focused on theoreticians who focus their research, concepts about black representation and identity, such as: Augel (2010), Bispo (2011), Hall (1997, 2003, 2005), Santos (2015), Sousa (2018). Another strand of approach concerns information about Ubirajara Fidalgo's biography and theatrical production, grounded by authors such as: Fidalgo (2017), Freitas (2013), Rezende (2017), Santos (2014). It is also proceeded by the reading and analysis of the play Desfuga, highlighting and examining if the passages in which are verifiable the alternating ways in which the protagonist relates to the black identity.

\footnotetext{
${ }^{1}$ Nascido em Teresina-PI. Graduado em Letras- CESC/UEMA. Especialista em Língua Portuguesa. Mestre em Literatura-UFPI. Doutor em História/ UNISINOS-RS. Professor da Educação Básica em Caxias-MA. Coordenador do projeto de extensão (UEMA) "As artes cênicas apresentam... a Literatura Caxiense. Professor Adjunto I do CESC/UEMA. E-mail: Izuarruda2211@gmail.com

2 Nascido em 23 de julho de 2002 na cidade de Caxias, Maranhão. Graduando do curso de Letras Português, Inglês e literaturas. E-mail: ykarobooks@gmail.com
} 
Keywords: Black identity. Resistance. Theater.

\section{Tecendo considerações sobre identidade negra e sua representação}

Esse tópico tem como base os processos de elaboração das identidades étnico-raciais em nosso país, possuindo, então, como objetivo levar o entendimento de aspectos que caracterizam tais processos. Primeiro, serão estabelecidas algumas informações sobre como são formadas tais identidades, tendo em mente que para isso é necessário enfocar o ponto de vista histórico, haja vista que identidades são construídas através de um conjunto de fatores que atravessam o tempo.

Esse debate é feito com base na Teoria das Representações Socias de Stuart Hall, concernente ao conjunto de conhecimentos, opiniões e imagens que permitem evocar um dado acontecimento, pessoa ou objeto. Estas representações são resultantes da interação social, pelo que são comuns a um determinado grupo de indivíduos.

Segundo Hall (1997), é através do uso que fazemos das coisas, alinhado com o que dizemos, pensamos e sentimos-como as representamos- que são atribuídas a elas significados. Em certa medida, instituímos significados aos objetos, pessoas e eventos, através da estrutura de interpretação que desenvolvemos, da forma como integramos esses objetos em nossas práticas do cotidiano.

Um dos conceitos que, modernamente, está relacionado aos estudos acerca da formação identitária do negro refere-se à diáspora. Originalmente, ela é proveniente da história de dispersão do povo judeu pelo mundo. Nos dias de hoje, seu significado foi importado para a história do povo negro capturado, escravizado e, desta forma, também espalhado por outros continentes durante o período colonial e, posteriormente, foi todo esse procedimento que deu origem ao que ficou conhecido como diáspora africana ou diáspora negra.

Devido à diáspora, houve o rompimento com as lembranças de um período antes vivido, que implica em um apagamento e na quebra do cordão umbilical com a África, colocando em pedaços as definições antes já existentes, provenientes desta matriz para a elaboração das identidades étnico-raciais. O que se coloca é que os deslocamentos, como no caso das diásporas, requerem a ressignificação das identidades, pois, a partir daí, surgem novas circunstâncias com as quais os sujeitos 
se deparam, quer no caminho, quer nos portos de chegada, com a solicitação de novas e distintas posições como sujeito (BISPO, 2011).

A dinamização das relações sociais por meio da queda de algumas fronteiras e a expansão de novos horizontes, que possibilitou vastidão de conhecimento, tem solicitado a redefinição do aparato conceitual e analítico com que os acadêmicos abordam os temas contemporâneos. Tendo em mente isto, é notável a necessidade de existir um arcabouço conceitual nem sempre linear, composto de ferramentas que sejam pertinentes à análise da conjuntura em que são postas e se engendram identidades na atualidade.

É evidente que os deslocamentos daqueles cuja vinda foi como escravos para os países da diáspora negra, bem como o contato com outros territórios, culturas e sujeitos, tenham causado uma desestabilização nas identidades culturais, de africanos e seus descendentes.

A identidade é uma "celebração móvel": formada e transformada continuamente em relação às formas pelas quais somos representados ou interpelados nos sistemas culturais que nos rodeiam (HALL, 2005). Ou seja, é definida de maneira histórica e não biológica. "O sujeito assume identidades diferentes em diferentes momentos, identidades que não são unificadas ao redor de um "eu" coerente" (SANTOS, 2015, p. 53).

Hall (2005) defende que a identidade somente se torna um problema quando está em crise, que é quando algo que apresentava uma suposta coerência e estabilidade é, então, deslocado por discursos e representações que contestam, propõem dúvidas e apontam incertezas. Piza (1998 Apud 2002, p. 41) relata algo que comprova isso:

...no discurso dos brancos é patente uma invisibilidade, distância e um silenciamento sobre a existência do outro "...não vê, não sabe, não conhece, não convive...". A racialidade do branco é vivida como um círculo concêntrico: a branquitude se expande, se espalha, se ramifica e direciona o olhar do branco.

A não-contestação da identidade do branco o leva a maiores condições de estabilização de sua identidade. Não há choques ou cobranças, de modo que não há crises. Por sua vez, a identidade do negro é constantemente colocada em causa por discursos que pregam a "mulatização" das identidades. É dada ao Brasil a designação de um país moreno, em consequência disso são notáveis a diminuição, 
eufemismo e subterfúgios empregados para mascararem a realidade, que claramente é de uma população negra. Inclusive, há as condições financeiras desvantajosas e que foram, através do tempo, preestabelecidas e impingidas aos negros e negras de nosso país.

Em decorrência disso, surge um quadro de exclusão, que, por sua vez, abre uma fenda social que coloca em seu interior o negro marginalizado de múltiplos setores. Isso o impede de ter seus direitos respeitados e intercepta de se apropriar de benefícios sociais de forma plena e digna. Tem-se uma herança do escravagismo que integrou a história do Brasil durante um longo tempo; aos escravos, não era designado direitos protetivos, mas deveres espoliantes.

Para Hall, a afirmação da identidade negra é imprescindível diante do racismo nos seus vários aspectos e níveis da formação social, política, econômica ou cultural:

Entre nós, a identidade é irrevogavelmente uma questão histórica. Nossas sociedades são compostas não de um, mas de muitos. Suas povos origens não são únicas, mas diversas. Aqueles aos quais originalmente a terra pertencia, em geral, pereceram há muito tempo - dizimados pelo trabalho pesado e a doença (HALL, 2003, p. 30).

Infere-se que é impossível pensar nos processos que constituem a identidade negra em nossos dias sem ao menos citar toda a história precedente de escravização, que inicia desde os tempos da colonização. Nesse quadro temporal, é que se deu a captura e dispersão dos negros através do globo, constituindo a chamada diáspora negra. Também não se pode deixar de mencionar algumas das consequências que a diáspora africana trouxe, sendo elas: dispersão, desterritorialização e expropriação. Gerou, através disso, uma séria crise de identidade para os negros levados, na condição de escravos, para diversos países ao redor do mundo.

É conveniente lembrar o que é revelado pelo crítico Kabena Mercer, para quem "a identidade somente se torna uma questão quando está em crise" (apud HALL, 2005, p. 9). Em síntese, o que acontece é o descentramento do sujeito de si mesmo e de seu lugar no mundo, fazendo com que surja um duplo descolamento (gerador de crise identitária para os negros), que foi descrito e analisado por Paul 
Gilroy em seu livro O Atlântico negro: modernidade e dupla consciência, publicado no ano de 2001.

Essa característica de ambivalência que predomina no mundo contemporâneo, está presente não só entre os afrodescendentes. É mais como um atributo presente em qualquer cultura hibridizada. Augel (2010, p.189) afirma:

As identidades estão localizadas num espaço e num tempo simbólicos e estão envolvidas naquilo que Edward Said denomina de geografias imaginárias, com suas paisagens características, seu senso de "lugar", de "estar-no-mundo", mas igualmente com a necessidade de detectar uma origem, uma história, um fundamento.

Ao serem submetidos à escravização, os negros foram desarraigados de suas terras e tradições, adentrando em espaços outros nos desumanos navios negreiros, a partir daí já tinha a si mesmo como sujeitos descentrados, pela condição que Ihes fora historicamente tachada. Ao atravessarem oceanos, tornamse seres diaspóricos que foram, prematuramente, desenvolvendo a dupla consciência de identidade, em relação ao continente de seu itinerário atual e ao espaço de sua origem.

Agora é importante firmar atenção em como ocorreu a (re)construção da identidade e da africanidade enquanto entes diaspóricos. O processo de resgate da memória pela resistência negra para a construção da história e da nova identidade na diáspora está fortemente presente na escrita de muitos romancistas e poetas afrodescendentes nas Américas, como: Aimé Césaire, Nicolás Guillén, Langston Hughes e outros.

Em alguns versos no poema Sou negro, de Solano Trindade, é notável o sentimento de identificação com o continente africano:

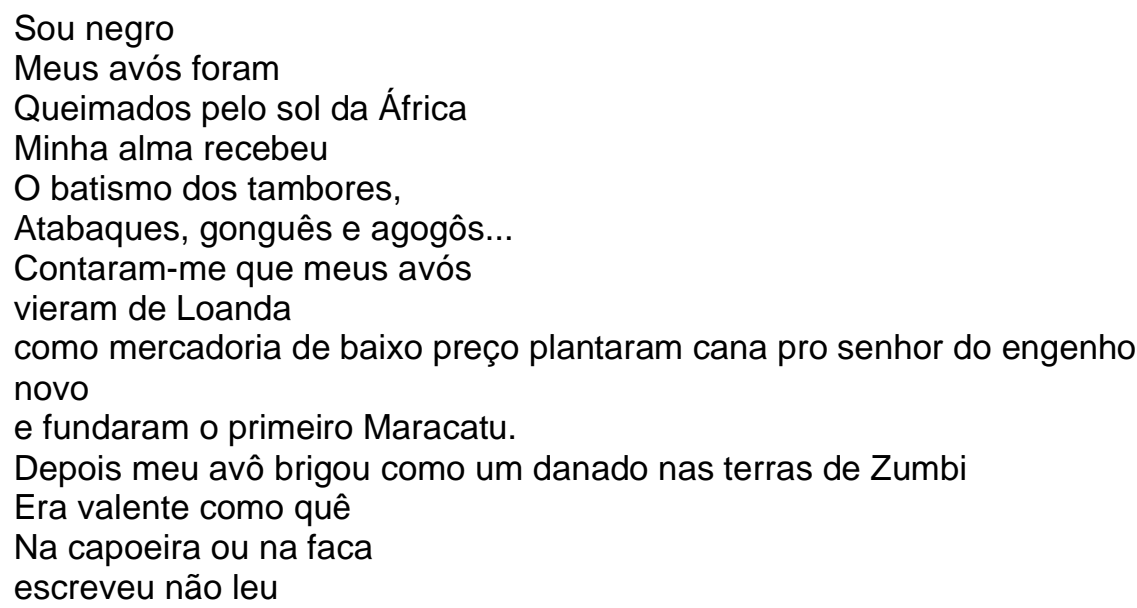




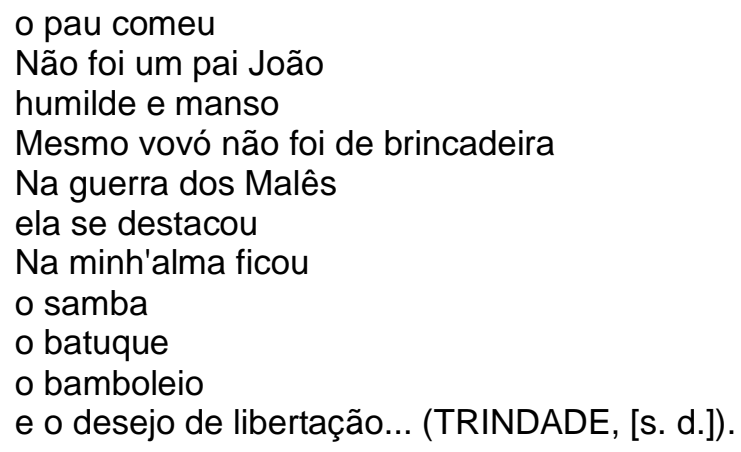

Nesse poema, o eu lírico afirma com orgulho a sua ancestralidade e é interessante verificar, na estrutura do texto literário, os fragmentos de eventos importantes, que são episódios da história referente ao período escravagista. A escrita do poema enaltece o orgulho da raça negra como resistência a todo um processo de desconstrução identitária, bem como revela, ainda, uma postura crítica ante as injustiças que ocorreram durante esse período e que tem reverberações na atualidade. Acerca de Solano e sua obra, Bernd (1988, p. 89) afiança:

\begin{abstract}
A marca registrada da poesia de Solano Trindade será a obsessão da reconstituição histórica, revelando a caminhada do poeta do conformismo à resistência. Devolver ao negro o orgulho de sua ancestralidade e ressignificar palavras estigmatizadas como navio-negreiro, transformando seu sentido histórico em referenciais positivos, parece ser a intenção primeira do poeta.
\end{abstract}

Conclui-se, que é a partir da memória que se estabelece a reconstituição do sujeito e consolidação da identidade dos negros. A memória preserva toda uma gama de aspectos culturais e afetivos que podem até adormecer, mas não desaparecem e podem ser acionados por um indivíduo ou um contingente humano. A literatura pode se configurar em um meio relevante no processo de resgate da memória coletiva do povo negro; em consequência disso, causa a reintegração dos componentes culturais espalhadas no tempo e no espaço ao redor do mundo. A seguir, tem-se os informes acerca da vida e obra de um literato que confiava na força da literatura/ gênero dramático para denunciar o racismo e valorizar a negritude em nosso país.

\title{
Ubirajara Fidalgo: uma voz teatral da representatividade negra
}


Ubirajara Fidalgo está consignado como um dos pioneiros na formação de grupos teatrais no Brasil constituídos, em sua ampla maioria, por negros e que possuíam as reflexões sobre a condição do ser negro em nosso país como um dos principais eixos temáticos de suas produções cênicas. Fidalgo, seguindo a trilha de Abdias do Nascimento, o precursor na luta pela representatividade do negro nas artes brasileiras, desfraldou com destemor e muito engajamento essa mesma causa, servindo-se do teatro para difundi-la.

Nascido em Caxias, em 1949 e falecido em 1986, demonstrava, desde criança, pendores para a arte teatral, como declarou sua filha Sabrina Fidalgo em entrevista concedia à revista Legítima Defesa: "Minha avó sempre me contou que ainda muito cedo meu pai já era uma criança diferente, uma criança instigada, era tipo uma criança meio louca. Ele já fazia teatro de fantoches com pedrinhas e coisas assim, coisas que ninguém nunca tinha visto lá, no meio do mato. (FIDALGO apud REZENDE, 2017, p. 69). Era, portanto, uma criança de imaginação muito fértil, capaz de fazer com que pedras ganhassem vida, se transformassem em seres humanos, revelassem voz e sentimentos. Criava um universo diferenciado, só seu, distinto da realidade tangível e não regida pelas leis inexoráveis da natureza. Era o teatro sendo gestado na alma do pequeno Ubirajara.

Uma curiosidade acerca da origem do sobrenome Fidalgo é destacada por Sabrina Fidalgo, filha de Ubirajara; ela rememora o que fora dito por sua avó:

\begin{abstract}
Em 1888, quando foi promulgada a Lei Áurea, os senhores dela (Prudência) resolveram dar presentes a alguns dos ex-escravos em razão da promulgação da lei. E perguntaram para ela o que ela gostaria de ganhar de presente. $O$ nome dela era Prudência, e ela respondeu que queria duas coisas: terras e um sobrenome. Porém, os senhores disseram que colocariam um 'da Silva' qualquer nela. Mas ela disse que não, que queria outro nome. Ela disse que queria se chamar Fidalgo. Por algum motivo ela ouvia muito esse nome na época. Daí disseram que Fidalgo não era sobrenome, mas ela bateu o pé e disse que queria se chamar Fidalgo, e assim foi feito (FIDALGO apud REZENDE, 2015, p. 68 ).
\end{abstract}

Como se pode perceber a avó de Ubirajara já manifestava o desejo de uma representatividade, nem que fosse na incorporação de um sobrenome que era indicativo de uma condição que emanava status e respeito. A palavra fidalgo era ouvida pela senhora Prudência como um atributo extremamente positivo, elogioso e definidor de valorização. Livre do subjugo escravo, ela também queria ter a liberdade de escolher o seu sobrenome, possuir uma autonomia acerca da identidade que iria 
assumir dali por diante. Parece que Ubirajara teve a quem puxar, como se diz no Nordeste, no que se refere à adoção de uma postura firme e determinada e na consciência de valorização da sua negritude e a de seus irmãos de etnia.

Depois de ter alguns contatos iniciais com a arte teatral em Caxias, Fidalgo desloca-se para São Luís, logo matriculando-se em um curso de Teatro para aprimorar-se como ator e dramaturgo. Um dos seus primeiros professores de artes cênicas foi Jesus Chediak, que havia sido contratado com vistas a formar um elenco de um espetáculo que reinauguraria um conhecido teatro da capital maranhense. $O$ professor revela que se sentiu impressionado com o talento artístico de Ubirajara. Também declara em uma entrevista em vídeo concedida em 2015:

\begin{abstract}
Eu fui dar o curso e só tinha um negro. E eu tinha um carinho especial por ele e a gente tinha uma empatia muito grande. Dei a ele tudo o que eu podia dar de conhecimento. Depois passam-se os anos e a gente veio a se encontrar aqui no Rio... e aí eu fiquei feliz disse: ah, Ubirajara, você seguiu... E o Ubirajara era uma pessoa... E o Ubirajara era uma pessoa muito desenvolta! Ele se destacava das outras pessoas, ele se colocava, se distinguia (CHEDIAK, 2015).
\end{abstract}

O fato de Fidalgo ser o único negro no curso de teatro acima mencionado é algo destacável e revelador do certo pioneirismo que o ator e futuro dramaturgo deseja estabelecer, o que é constatável pelo fato de que ao chegar no Rio de Janeiro, após a participação em alguns espetáculos, resolve fundar, no início dos anos de 1970, o Teatro Profissional do Negro (TEPRON). Um dos motivos para a fundação foi quando constatou a pouca participação de negros em espetáculos teatrais, sendo que, quando isso ocorria era-lhes designados papeis quase que de figuração, sem relevância no enredo e reforçadores da desvalorização dos afrodescendentes na produção cênica. No referente a negros que escreviam para o teatro, a carência era mais alarmante ainda. No atinente ao TEPRON, Freitas (2013, p. 1) assevera:

\footnotetext{
O Teatro Profissional do Negro (TEPRON) concebido por Ubirajara no início da década de 1970 no Rio de Janeiro, capacitava, fazia política e crítica social dentro dos palcos em uma época em que a temática negra era constantemente abrandada e utilizada a serviço do ideal enganoso da miscigenação integradora, difundida pelo governo militar brasileiro.
}

Como se pode averiguar, no teor da citação acima, o TEPRON firmava-se em um ideário de realizar ações artísticas que trouxessem à baila, de forma crítica, a situação social em que estava imerso o negro no Brasil. Não compactuando com a 
falsa ideia propagada na Ditadura Militar de uma democracia racial, a pretensão era a de dar real visibilidade a uma parcela étnico-racial da população brasileira que vivia à margem da sociedade e que não ocupava protagonismo na cena artística em nosso país. A companhia investia também na formação cênica de atores negros, preparando-os para exercerem o ofício de interpretar com qualidade e poderem viver nos palcos personagens que protagonizassem as produções dramáticas. Em uma atitude inovadora, eram oferecidos cursos de interpretação para moradores de favela.

No atinente às temáticas contempladas pelos textos escritos pelo coordenador do TEPRON, tem-se a seguinte informação: "Racismo, misoginia, homofobia, desigualdade social e a Ditadura Militar eram temas abordados diretamente pelos textos de Fidalgo. A partir de 1980, passou a realizar, depois dos espetáculos, debates políticos, o público e ele" (SOUSA, 2015, p. 345). É interessante notar que, muitas vezes, após os espetáculos, havia um debate com a plateia e convidados acerca dos assuntos apresentados e que refletiam os problemas de racismo, marginalização e descaso, vivenciados pelo negro brasileiro. Era a proposta de fazer com que o teatro fomentasse reflexões relevantes e que resultassem na modificação de posturas para se avançar a caminho da construção de uma sociedade menos injusta e preconceituosa.

Ubirajara Fidalgo mostrava-se munido de coragem para o enfrentamento das barreiras que se erguiam diante da pretensão de formar atores e dramaturgos negros, propiciando que apresentassem seus trabalhos a uma plateia. Pode-se dizer que era um ativista cultural, comprometido com as causas que tocavam diretamente na maneira como o negro era visto e tratado no Brasil. Possuía a confiança de que a arte, especialmente o teatro, poderia ser um poderoso instrumento de disseminação e afirmação do talento do artista negro.

Joel Rufino dos Santos, importante historiador brasileiro, também revela a sua visão acerca de Ubirajara; ei-la:

[...] Fez muita coisa em sua curta vida - quase uma sina dos dramaturgos negros contemporâneos -, foi bailarino, figurinista, professor, mas prevaleceu nele, todo o tempo, a vontade de um teatro político negro. Teve sua própria companhia, o TEPRON, cuja meta era elevar o artista negro ao mesmo patamar do culto. Evitou a folclorização e a diminuição da sua arte, pondo em cena a condição humana implicada, por assim dizer, nos problemas raciais que admitia e enfrentava como militante do movimento negro. (SANTOS, 2014, p. 168) 
O palco seria um espaço no qual a voz do negro seria pronunciada com destaque, pois, nos espetáculos dirigidos por Fidalgo, os temas estavam alinhados com os problemas que afligiam essa parte da população brasileira. As peças traziam negros como personagens centrais e os enredos, com nuances de crítica social e política, giravam em torno das mais diferentes situações que envolviam os protagonistas. Dentre as peças escritas pelo coordenador do TEPRON, elenca-se: Os Gazeteiros, A Boneca da Lapa, Desfuga, A Superexcitação, Tuti. Sobre a versatilidade e politização de Ubirajara Fidalgo, segue a declaração: "Além de seu trabalho enquanto dramaturgo, ator, produtor e diretor, nunca se afastou da militância, tendo participação fundamental na fundação do Instituto de Pesquisa da Cultura Negra (IPCN) e da Associação Cultural de Apoio as Artes Negras (ACAAN) junto ao historiador e escritor negro Joel Rufino dos Santos” (FREITAS, 2013, p. 1).

O fundador do TEPRON não ficou circunscrito ao desenvolvimento de ações apenas no âmbito das artes cênicas, mas também esteve integrado a entidades que tinham o intuito de valorizar a cultura e as artes dinamizadas pelo negro. Ele buscava de fato, com a utilização da arte, abrir os espaços para que a representação do negro fosse manifestada e respeitada. Acentuando a relevância de Ubirajara como um homem vinculado ao ativismo sociocultural, eis o que é declarado:

Hoje, com todas as informações sobre suas atividades, devemos considerálo como um elemento importante do Movimento Negro no Brasil entre as décadas de 1970 e 1980. Foi um dos fundadores da ACAAN (Associação Cultural de Apoio às Artes Negras) e, ainda, foi empresário, ator, dramaturgo, produtor, estilista, modelista, apresentador de TV e diretor de teatro, não sem 0 apoio da esposa e companheira Alzira Fidalgo (REZENDE, 2017, p. 42) .

Ubirajara Fidalgo, tanto em suas encenações quanto em suas atividades em órgãos de representatividade dos afrodescendentes no Brasil, buscava efetivar um trabalho de politização do negro, ressaltando a importância da assunção do seu papel como cidadão. Dentro do exercício dessa cidadania, o negro deveria empreender lutas que reivindicassem o respeito e a garantia de seus direitos, não se calando ante as arbitrariedades promovidas por condutas alicerçadas pelo racismo. O criador do TEPRON, um caxiense pouco conhecido por seus conterrâneos na 
atualidade, falece em 1986, deixando relevantes contribuições para as artes cênicas no Brasil. Hoje, o legado de Ubirajara encontra eco, em sua filha, Sabrina Fidalgo, cineasta e cidadã atuante nas causas vinculadas à valorização da identidade negra.

\section{As nuances da representação da identidade negra na peça Desfuga, de Ubirajara Fidalgo}

Desfuga é um monólogo escrito por Ubirajara Fidalgo. A peça teatral é protagonizada por Zé Baiano, um homem negro que, de acordo com o próprio autor, apresenta sinais mestiços por ser filho de uma mãe negra e um pai branco, tem por volta dos seus 50 anos, é "escolado e astuto". O monólogo tem como cenário uma sala de escritório- desprovida de luxo, contendo um conjunto de sofá, mesinha, um arquivo-estante e, ao lado, um pequeno altar com santos e orixás, além de uma pequena acesa. As falas da peça são principiadas no momento em que o protagonista atende ao telefone e começa a conversar com seu melhor amigo e padrinho de sua única filha.

Dentro de um quadro de certas fraturas na assunção, pelo protagonista, de uma identidade negra, no âmbito da religiosidade, não é observada qualquer inconstância ou rejeição quanto à adoção de ritos e crenças de origem afro. Dentro dessa vertente de fluidez identitária, Hall (2005) enuncia que o sujeito assume variadas identidades em circunstâncias distintas da vida, não havendo uma identidade integralmente imutável e plenamente constituída, imune de fluxos processuais das vivências humanas. O protagonista revela, logo no início do texto dramático, sua vinculação à religião afrodescendente. Como é verificável no fragmento que segue:

Quase me desgraçaram todo não fosse meu Xangô... (vai ao altar) Saravá! Eu não tinha me livrado dessa, mas agora é diferente, meu irmão! Eu tô de cabeça feita...Aqui, meu filho (abre a camisa e mostra a guia cruzada), é corpo fechado. Na carcaça de Zé Baiano, mandinga não entra...não entra porque meu Xangô e mãe lansã, eparrê, não deixa, não deixa, malandro! Eu lavei a escada do Bonfim, tomo bando de alho com casca de eucalipto, palmas de castanheira e mais e mais. Eu tô firme, Genival, tu sabe disso! (FIDALGO, s/d, p. 2). 
Como é bem constatável na fala e atitudes de Zé Baino, há uma forte aproximação dele com o Candomblé e seus ritos, o que revela uma relação umbilical com a religião criada pelos seus descendentes. A personagem evoca os nomes de orixás de origem africana (Xangó, lansã); essas divindades são mencionadas como responsáveis pela sua proteção ante as "mandingas", trabalhos maléficos feitos para causar prejuízo a alguém. É interessante notar que a devoção a Xangó (orixá da justiça) é tão elevada que Zé possui um altar dedicado a essa divindade em seu ambiente de trabalho.

A identidade religiosa do protagonista está imersa nas águas do misticismo africano. Também, dentro dessa cultura da religião africana, é relatado alguns procedimentos protetivos adotados, como "tomar banho de alho com casca de eucaliptos", rituais que são incorporados, com naturalidade, pela personagem principal da peça. Na esteira de conceber a religião como uma cultura de afirmação identitária, Sousa $(2018$, p. 5) declara: "A religiosidade dos negros africanos foi se constituindo a partir da necessidade de manter viva a cultura africana. Seus costumes, suas danças e seus ritos aos orixás foi uma forma de afirmação dos elementos da identidade negra".

A personagem Zé baiano revela, em alguns momentos da peça, a dificuldade em se identiifcar como negro, no referente a suas carcaterísitcas físicas afrodescendentes, sentindo-se ofendido quando assim é designado como negro pelo seu melhor amigo, como se pode averiguar a seguir:

Ah, Genival que é que está acontecendo camarada? Continuas com esse papo pra cima de mim... não vem com essa não senhor. Nada disso... escuta... Crioulo né? . Estás me xingando de crioulo não é? Pois fique sabendo pela milésima vez que eu sou crioulo mesmo...Taí, pois fique sabendo...Como? Negro? Negro não! Oh, Genival, não esculacha não cara... Eu sou crioulo, mas não sou negro.. Que é que há, meu irmão? Então tu não ouviu falar que mainha é preta mas se safou com um branco? (...) sou filho da preta com branco! Sou crioulo, mas não um crioulo negro, eu já sou um crioulo mulato(FIDALGO, s/d, p. 3)

Zé Baiano justifica de não se identificar como negro pelo fato de, embora com mãe negra, ser filho de um homem branco, admitindo até ser chamado de crioulo, equilivalente, em sua visão, a mulato de pele mais clara que um preto retinto. A denominação de negro é julgada por ele como um xingamento, um qualitativo de carga pejorativa e enunciadora de uma inferioridade no âmbito social. 
Essa não aceitação de negritude por não possuir uma tez demasiadamente escura, o que, em sua concepção, promoveria um racismo ainda maior, está associada ao colorismo dentro da tonalidade de pele dos negros, visto por Silva (2021, p. 9) como "forma de discriminação baseada fundamentalmente na tonalidade da pele: quanto mais escura uma pessoa, mas discriminação e exclusão ela sofreria".

Tal postura tem sua raiz na infância, na conduta de sua mãe ao dizer, repetidas vezes, que ele deveria, assim como ela fizera, casar com pessoa de tez branca para clarear a sua prole vindoura. Ele revela: "Quando me entendi como gente já encontrei a mamãe às voltas com essa obssessão de clarerar a família". (FIDALGO, s/d, p. 19 ). Zé baiano apieda-se da mãe e diz que ela só estava, com essa atitude, tentando afastar de vez a desalentada sina que acompanhou a avó e a bisavó que tiveram como lar uma senzala e sofreram, a base de chicotadas, os castigos imputados aos escravos. Lembrando que Zé Baiano adota os conselhos da mãe e casa-se com uma mulher branca de olhos claros, tendo uma filha com essas mesmas características.

A visão transmitida ao filho era de um certo envergonhamento por pertencer a uma descendência negra. O protagonista infere que asumir a sua identidade negra é assumir a sua condição de subalternidade, algo contra qual lutou por um considerável tempo de sua vida. A mudança de visão do protagonista ocorre no momento em que ele não é convidado pela filha para a festa de formatura. Ele só toma ciência do evento porque seu melhor amigo e compadre liga para saber se Zé Baiano já está pronto para ir à festa. Assustado, ele começa a questionar o porquê de sua filha, pela qual realizara enormes sacrifícios, inclusive para que ela tivesse a melhor educação possível, não o convidou para participar da coroação de uma etapa tão relevante da vida de um jovem. Eis as conclusões a que chega:

A verdade é que ela queria que eu ficasse de fora, não soubesse do dia da festa, para não não comparecer lá porque ... Porque ...Ela tem vergonha de mim...Vergonha de mim! Absurdo! Por que ela teria vergonha do pai... Por eu ser suburbabo...Como ela diz brincando...Por eu ser...Ser...Ser mais o quê? Por que será? ...Será por que eu sou negro?!... É vai ver que é isso mesmo...Aliás tá muito claro até (....) Ela tem uma família toda branca..Padrinho branco, professores brancos, amigos brancos...Namorado e família tudo super branco, vai ver que até tomam banho com sabão em pó, os miseráveis; pois bem, com toda essa brancura em volta dela, um pai crioulo desquitado da mãe, tem mesmo que ficar por fora (FIDALGO s/d, $p$. 9) 
Após algumas reflexões, chega à conclusão de que a sua filha tinha vergonha do pai por ser ele negro. Ela está noiva de um rapaz branco, nunca apresentado ao pai negro, o padrasto e o padrinho também são brancos, ambos estarão na festa para a qual Zé Baiano não fora convidado. Ele chega a dizer, no excerto acima, que a filha estava cercada de brancura por todos os lados e que, com tal circunstância, não haveria espaço para um pai afrodescendente. Ele vai relembrar as desculpas mal ajambradas que a filha dava para que ele não fosse asuas festas de aniversário na adolescência e juventude. Inicia uma releitura de memórias, agora com novas colorações, em que ele constata as atitudes racistas da jovem Elisabete, a pessoa que mais amara na vida e que, em muitas ocasiões, o desprezara simplesmente por ser negro. No entanto, ele dera exemplo, pois também mostrava desprezo pela sua negritude; portanto, contribuiu para essa formação de comportamento em Elisabete. Zé Baiano se dá conta disso, como é verificável no trecho seguinte:

É isso mesmo, essa menina não tem culpa de estar me rejeitando agora não... Ela só está seguindo à risca o que foi preparado para ela ...A coisa vem de longe...Como é que ela pode a essas alturas do campeonato querer um pai preto quando tudo foi preparado para que ela fosse uma branca, vivendo num mundo branco, onde negro é sinônimo de inferioridade? Eu não posso querer isso agora de minha filha... porque eu tenho que reconhecer que quem preparou essa cama para ela foi eu... eu sempre quis que o filho que eu tivesse não fosse como eu, mais para preto do que para outra coisa (FIDALGO, s/d, p.18-19).

Nessa afirmação, Zé Baiano revela-se compreensivo em relação ao que a filha havia se tornado, admitindo a sua considerável contribuição na forma insensível e desrespeitosa com que a jovem via os negros. Como ela poderia ter orgulho de seu pai ser negro se ele mesmo demonstrava certa ojeriza pela sua etnia afrodescendente. Ele sente-se responsável por ter circundado a filha, desde a mais tenra idade, de um enaltecimento da denominada cultura eurocêntrica, em que até as bonecas que entravam em casa eram louras de olhos azuis. Como ele mesmo afirma: "...tudo foi preparado para que ela fosse branca”. Em nenhum momento, da formação de sua cria, ele dialogou ou buscou demonstrar a beleza e riqueza da cultura negra. Zé Baiano, na verdade, nunca deixou de se sentir inferior por ter na pele e no sangue a africanidade preta, tal sensação teve a gênese com sua progenitora, dona de discursos de menorização da raça e da necessidade de 
branqueamento dos descendentes. Baiano alinhava-se a uma representação compatível com o que revela Santos (2015, p. 57):

Representar é, pois, uma negociação entre significados e sentidos que os sujeitos trazem consigo e as demandas que se colocam como solicitação de novos significados. Disso resulta a negociação entre os significados e sentidos que compõem as representações que os sujeitos admitem e os significados e sentidos que os discursos e contingências os convocam a assumir.

Na esteira, ainda, das reflexões emanadoras de uma conscientização, Zé Baiano externa a insatisfação da pouca representatividade que os negros possuem nas propagandas e programas de TV, espaços em que o protagonismo é quase integralmente das pessoas brancas. Eis o que é dito por Baiano:

\begin{abstract}
Nas propagandas de televisão, os comerciais só mostram gente branca, crianças brancas; se aparece uma criança negra é sempre uma no meio de muitas e geralmente não tem significado positivo; é apenas mais uma no meio da multidão. Quando aparece um negro bonito na televisão é porque é propaganda de henê para deixar os cabelos iguais aos cabelos de branco: soltos e balançantes ...Quando não é isso, o que se vê é crioulo na cozinha, limpando o chão, sendo escravo e tudo que existe de função subalterna.(FIDALGO, s/d, p. 18).
\end{abstract}

No excerto acima, é focalizado o quanto os negros não se veem verdadeiramente representados na publicidade e programas televisivos, sendo que, quando aparecem na mídia, via de regra, é numa versão estereotipada e preconceituosa. Com muita frequência, nas novelas da década de 1980, período de produção da peça, cabia ao negro o papel de serviçais de pouca formação intelectual, com falas muito restritas, assumindo a função estigmatizada de quase figurantes, sem uma relevância consistente na trama. $\mathrm{Na}$ atualidade, tem-se algumas melhorias nesse contexto, mas ainda longe de uma adequada equanimidade racial nas produções artísticas televisas.

Um outro ponto destacável por Zé Baiano é que o negro só é figura principal em comerciais para legitimar a valorização de um aspecto físico do europeu, no caso em tela: o cabelo liso de pessoas brancas em detrimento dos cabelos crespos que, via de regra, identificam um autêntico afrodescendente. $\mathrm{O}$ alisamento capilar por pessoas negras revela a descaracterização de um traço identificador da etnia a 
que elas pertencem. Tal atitude por parte de alguns revela a tentativa do chamado branqueamento, que, dentro do espaço temporal da peça (década de 1980), "a despeito de ser ignorado por alguns negros, permanecia sendo altamente valorizado e superestimado, uma vez que demonstrava que a lógica da supremacia branca exercia sobre o povo negro tinha gerado resultados" (SILVA, 2021, p. 10).

$\mathrm{Na}$ tomada de consciência de seus erros e omissão no referente à relação estabelecida com a sua identidade afrodescendente, o protagonista do texto dramático de Ubirajara Fidalgo ainda declara:

\begin{abstract}
Por não ter sido um negro de verdade eu não impus o respeito na casa da minha mãe, não defendi as minhas irmãs, não apoiei ninguém, como era devido... Os anseios que eu senti de me voltar para o meu povo perdido, eu não assumi por covardia, porque me justificava intimamente que não poderia carregar o mundo nas costas e que os problemas dos negros não poderiam ser solucionados por mim (...) No meu caso, eu me omiti, deixei de fazer a minha parte em várias oportunidades...Quando poderia ter aceito ser negro (....). (FIDALGO, p. 20-21)
\end{abstract}

No trecho acima destacado, é bem patente uma autoanálise que Zé Baiano efetiva, focalizando a sua inação no referente a ter se eximido de adotar uma postura de respeito a si e aos seus na condição de descendentes do povo preto. Ele se autodenomina de covarde por não assumir uma atitude de luta em prol da defesa da valorização do negro nos diversos contextos opressivos da sociedade, optando por uma negligência a essa causa e, em determinados momentos, por um enaltecimento dos valores eurocêntricos. No âmbito da assunção de uma conduta dignificante que deveria ter sido deflagrada por Baiano e que o auxiliaria na resolução de certos conflitos pessoais, Bernd (1988, p. 42):

\begin{abstract}
Um verdadeiro modo de ser negro, logo, uma real identidade negra, se construirá na medida em que os negros conseguirem curar-se de sua amnésia cultural e tomarem as rédeas seu destino histórico. Este seria o passo adiante através do qual o negro, deserdado, recuperaria a sua essência de homem, passando a produzir os meios de sua própria história. Permitindo o surgimento de uma imagem positiva de si mesmo.
\end{abstract}

A personagem central do monólogo teatral, na parte final do texto dramático, mostra-se ciente do valor de sua identidade genética e conjectura que poderia ter sido um exemplo de um negro imbuído do orgulho de sua etnia, emanador de uma imagem positiva de si mesmo, como afirmou Bernd, o que, suspostamente, 
reverberaria no olhar respeitoso e afetivo que a filha teria sobre ele. É o próprio Zé Baiano que conclui: "Se eu me aceito como sou; negro como sou, tudo que eu fizer será para melhorar o negro que sou e não para deixar de sê-lo. Uma vez melhorando a mim mesmo, estarei contribuindo com a melhora dos que estão à minha volta".

\section{Conclusão}

O dramaturgo caxiense Ubirajara Fidalgo optou, na maioria de suas produções textuais de caráter dramático, aliar-se a uma arte de engajamento social ou de resistência, mas especificamente focando nos conflitos pessoais ou interpessoais vivenciados pelas personagens centrais no referente à identidade negra. O escritor, também fundador do Teatro Profissional do Negro (TEPRON), ao contrário do protagonista da peça aqui analisada (Desfuga), não se eximiu de revelar, por intermédio de seu fazer artístico e ativismo sociocultural, o orgulho de ser negro e de toda a representação de pertencimento cultural que isso gerava.

No texto analisado, Desfuga, Fidalgo traz à baila cênica uma personagem negacionista da sua condição, até mesmo fisicamente visível, de afrodescendente, buscando formas de efetivar certo branqueamento, como a aproximação, com o intuito de amizade, com pessoas brancas e casamento com uma mulher de pele bem clara e olhos azuis. Tal afastamento da sua negritude tem origem nos discursos racistas ouvidos desde criança, sendo alguns deles manifestados pela própria mãe. O teatrólogo promove uma conscientização do protagonista quando ele é vítima do desprezo preconceituoso da própria filha; a partir daí, Zé Baiano assume a sua identidade negra e reconhece todos os seus desacertos ao lidar com a representação de ser negro. Fidalgo faz de seu texto/peça um grito denunciador das visões sociais racistas, mas também aponta para as possibilidades de transformação por intermédio da conscientização do valor identitário do negro no Brasil.

\section{Referências Bibliográficas}

AUGEL, Moema Parente. Teatro Afro-brasileiro Contemporâneo. In: MENDES, Marília. A língua portuguesa em viagem - Actas do Colóquio Comemorativo do 
Cinquentenário do Leitorado de Português da Universidade de Zurique, 20 - 22 jun. 1996, editado por Marília Mendes, p. 121-150, 2003.

BERND, Zilá. O que é negritude. São Paulo: Brasiliense, 1988.

BISPO, Suely. Solano Trindade: negritude e identidade na literatura brasileira. In: RELL-Revista Eletrônica de Estudos Literários, Vitória, s. 2, ano 7, n.; 9, 2011.

CHEDIAK, Jesus. Entrevistando Jesus Chediak. Entrevista concedida a Girlene Verly Ferreira de Carvalho Rezende. [Gravação] Rio de Janeiro, Brasil, 2015.

FIDALGO, Ubirajara. Desfuga (texto teatral datilografado). In: REZENDE, Girlene Verly Ferreira de Carvalho. A dramaturgia do teatro experimental do negro (TEN) e do teatro profissional do negro (TEPRON): corpo e identidades. Tese (Doutorado em Estudos Literários). Belo Horizonte-MG, 2017.

FREITAS, Fernando Vieira de. Ubirajara Fidalgo e o dramaturgo negro: autonomia no Teatro Profissional do Negro na década de 1970 (2013). Disponível em: https: $</ /$ www.geledes.org.br/ubirajara-fidalgo-e-o-dramaturgo-negro-autonomia-no-teatroprofissional-do-negro-na-decada-de-1970-por-fernando-vieira-de-freitas/. Acesso em: 03/05/2018.

GILROY, Paul. O atlântico negro: modernidade e dupla consciência. Rio de Janeiro: 34, 2001.

HALL, Stuart. A centralidade da cultura: notas sobre as revoluções culturais do nosso tempo. Educação \& Realidade, Porto Alegre, v. 22, no2, p. 15-46, jul./dez, 1997.

HALL, Stuart. Da diáspora: identidades e mediações culturais. Belo Horizonte: UFMG, 2003.

HALL, Stuart. A identidade cultura na pós-modernidade. Rio de Janeiro: DP\&A. 2005.

PIZA, Edith. O caminho das águas: personagens femininas negras escritas por mulheres brancas. São Paulo: Edusp/Com-Art/Fapesp, 1998.

REZENDE, Girlene Verly Ferreira de Carvalho. A dramaturgia do teatro experimental do negro (TEN) e do teatro profissional do negro (TEPRON): corpo e identidades. Tese (Doutorado em Estudos Literários). Belo Horizonte-MG, 2017.

SANTOS, Elisabeth Figueroa dos. Das margens, escritos negros: relações entre literatura periférica e identidade negra: Monografia (Pós-Graduação em Psicologia). Universidade Federal de São Carlos. São Carlo/SP, 2015.

SOUSA, Vânia Maria Carvalho. Identidade e pluralidade: uma sacerdotisa afrobrasileira, negra e mulher. Revista Científica Multidisciplinar Núcleo do Conhecimento. Ano 03, Ed. 12, Vol. 04, pp. 85-108 dezembro de 2018. ISSN:24480959 
SOUSA, Isaac; MENESES, Renato Lourenço; Vianna, Jotônio. Cartografias invisíveis: saberes e sentires de Caxias. Caxias/MA: Academia Caxiense de Letras, 2015.

SILVA, Tainan Maria Guimarães Silva e. O colorismo e suas bases históricas discriminatórias. Disponível em https://revistas.unifacs.br/index.php/redu/article/viewFile/4760/3121. Acesso em: $12 / 04 / 2021$

TRINDADE, Francisco Solano. Poemas antológicos. São Paulo: Nova Alexandria, [s.d.]. 